\title{
RANCANG BANGUN SISTEM PENDUKUNG KEPUTUSAN PEMILIHAN SUPPLIER MENGGUNAKAN METODE SIMPLE ADDITIVE WEIGHT
}

\author{
Diki Susandi ${ }^{1}$, Hibia Lia Anita ${ }^{2}$ \\ ${ }^{1,2}$ Jurusan Teknik Informatika Fakultas Teknologi Informasi Universitas Serang Raya \\ Jln. Raya Cilegon Serang - Drangong Kota Serang \\ 11unsera.diky@gmail.com \\ 2liaanitah@gmail.com
}

\begin{abstract}
Abstrak - Pemilihan supplier merupakan salah satu aktivitas penting di dalam kegiatan perusahaan. Pemilihan supplier menjadi salah satu bagian kritis dalam aktifitas pembelian karena berdampak pada kualitas dan ketersediaan bahan baku, efisiensi biaya produksi dan kelancaran sirkulasi keuangan perusahaan. PT. Nikomas Gemilang merupakan salah satu produsen sepatu kualitas kelas dunia. Banyaknya supplier pada PT. Nikomas Gemilang membuat team purchasing kesulitan menentukan supplier mana yang memiliki performasi baik dari segi harga, kualitas dan kuantitas bahan baku. Selain itu, dalam memilih supplier pihak team purchasing masih menggunakan cara subyektif yaitu dengan berdasarkan pengalaman menjadi mitra kerja dan kedekatan dengan orang orang yang berpengaruh pada PT. Nikomas Gemilang. Sistem pendukung keputusan adalah proses pengambilan keputusan dibantu menggunakan komputer untuk membantu pengambil keputusan dengan menggunakan beberapa data dan model tertentu untuk menyelesaikan beberapa masalah yang tidak terstruktur. Metode dalam pengembangan sistem pendukung keputusan menggunakan metode simple additive weight $(S A W)$. Perancangan sistem menggunakan use case diagram. Hasil penelitian dapat langsung diterapkan dalam proses pemilihan supplier berdasarkan kriteria yang telah ditentukan.
\end{abstract}

Kata Kunci - Sistem Pendukung Keputusan, Simple Additive Weight, Supplier, Use Case Diagram, Kriteria.

\section{PENDAhUluan}

Dewasa ini banyak teknologi yang dikembangkan termasuk teknologi informasi yang bisa menyokong jalannya usaha bisnis yang dilakukan oleh suatu organisasi. Teknologi informasi telah memungkinkan pengambilan keputusan dapat dilakukan dengan lebih cepat dan cermat. Informasi sebagai output dari sistem pendukung keputusan, dapat disajikan dalam bentuk laporan yang dihasilkan melalui perhitungan atau model matematika.

Pemilihan supplier merupakan salah satu aktivitas penting di dalam kegiatan perusahaan. Pemilihan supplier menjadi salah satu bagian kritis dalam aktifitas pembelian karena berdampak pada kualitas dan ketersediaan bahan baku, efisiensi biaya produksi dan kelancaran sirkulasi keuangan perusahaan. [1]

PT. Nikomas Gemilang merupakan salah satu produsen sepatu kualitas kelas dunia. Produk yang dihasilkan antara lain sepatu basket, sepatu autoclave, sepatu skateboard, sepatu anak-anak, sepatu bola, sandal dan sepatu olahraga lainnya.
Dalam proses pembuatan sepatu yang dibutuhkan tidak hanya bahan baku, namun sparepart yang digunakan untuk mesin-mesin yang beroprasi juga berpengaruh besar untuk proses produksi. Jika mesin mati dan sparepart tidak lengkap maka produksi akan berhenti dan perusahaan tidak akan mencapai target dan akan mengalami kerugian. Dalam pemilihan sparepart juga tidak bisa sembarangan karena jika kualitas buruk akan berdampak buruk untuk produksi, maka dari itu pentingnya penyeleksian supplier secara ketat untuk menjaga kualitas produksi supaya tetap stabil.

Banyaknya supplier membuat team purchasing kesulitan menentukan supplier mana yang memiliki performasi baik dari segi harga, kualitas dan kuantitas bahan sehingga perusahaan bisa memprioritaskan supplier tersebut dalam memenuhi sparepart termasuk mesin yang dibutuhkan. Selain itu dalam memilih supplier pihak team purchasing masih menggunakan cara subyektif yaitu dengan berdasarkan pengalaman menjadi mitra kerja dan kedekatan dengan orang orang yang berpengaruh pada PT. Nikomas Gemilang.

Sistem pendukung keputusan ialah proses pengambilan keputusan dibantu menggunakan komputer untuk membantu 
pengambil keputusan dengan menggunakan beberapa data dan model tertentu untuk menyelesaikan beberapa masalah yang tidak terstruktur.

Sistem pendukung keputusan merupakan sistem informasi interaktif yang menyediakan informasi, pemodelan, dan pemanipulasian data. Sistem ini digunakan untuk membantu pengambilan keputusan dalam situasi yang semiterstruktur dan situasi yang tidak terstruktur, dimana tidak seorang pun tahu secara pasti bagaimana keputusan seharusnya dibuat. [2]

Salah satu metode penyelesaian masalah yang dapat diimplementasikan dalam sistem pendukung keputusan adalah dengan menggunakan metode simple additive weight $(S A W)$. Metode $S A W$ sering juga dikenal istilah metode penjumlahan terbobot. [3]

Berdasarkan permasalah tersebut, maka penelitian ini dilakukan dengan cara merancang sebuah sistem pendukung keputusan dengan menggunakan metode simple additive weight. Hasil penelitian dapat langsung diterapkan dalam proses pemilihan supplier berdasarkan kriteria yang telah ditentukan. Diharapkan dengan adanya sistem pendukung keputusan ini akan dapat membantu team purchasing dalam memilih supplier yang terbaik untuk pemenuhan kebutuhan bahan baku.

\section{Metodologi Penelitian}

\section{A. Model Pengembangan Sistem Informasi}

Model pengembangan sistem informasi yang digunakan dalam penellitian ini adalah dengan menggunakan model waterfall. Metode air terjun atau yang sering disebut metode waterfall sering dinamakan siklus hidup klasik (classic life cycle), dimana hal ini menggambarkan pendekatan yang sistematis dan juga berurutan pada pengembangan perangkat lunak, dimulai dengan spesifikasi kebutuhan pengguna lalu berlanjut melalui tahapan-tahapan perencanaan (planning), permodelan (modeling), konstruksi (construction), serta penyerahan sistem ke para pelanggan/pengguna (deployment), yang diakhiri dengan dukungan pada perangkat lunak lengkap yang dihasilkan. Tahapan metode waterfall dapat dilihat pada gambar di bawah ini. [4]

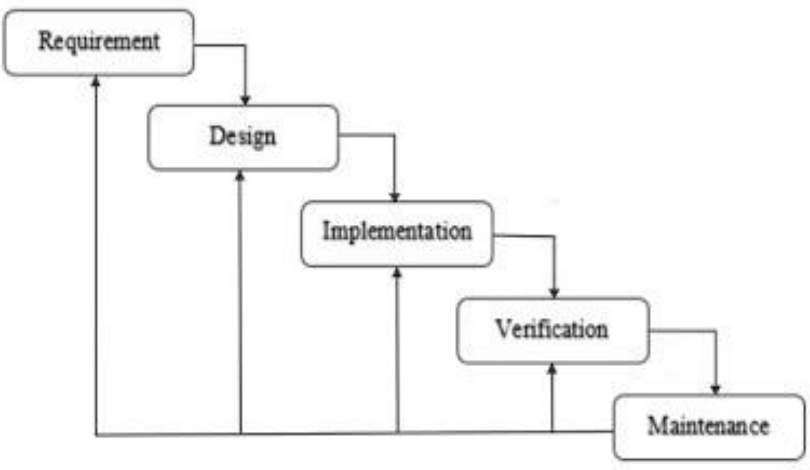

Gambar 1. Tahapan Model Waterfall

\section{B. Metode Pengumpulan Data}

Metode pengumpulan data dalam penelitian ini adalah sebagai berikut:

1) Studi pustaka: yaitu kegiatan menghimpun informasi yang relevan dengan topik atau masalah yang akan atau sedang diteliti, dari buku-buku ilmiah, laporan penelitian, karangan-karangan ilmiah, peraturanperaturan, ketetapan-ketetapan, jurnal, dan sumbersumber tertulis baik tercetak maupun elektronik lain.

2) Observasi: yaitu metode pengumpulan data melalui pengamatan langsung atau peninjauan secara cermat dan langsung di lapangan atau lokasi penelitian yaitu PT. Nikomas Gemilang.

3) Wawancara: yaitu proses dimana memberikan pertanyaan kepada atasan mengenai teknik pelaksanaan dan pemberi keputusan.

\section{Analisa Sistem Yang Berjalan}

Analisis sistem yang berjalan bertujuan untuk mengetahui lebih jelas bagaimana cara kerja sistem tersebut, sehingga kelebihan dan kekurangan sistem dapat diketahui.

Prosedur pengajuan permintaan pembelian barang dilakukan oleh user, dan akan diproses oleh bagian purchasing, prosedur yang berjalan yaitu:

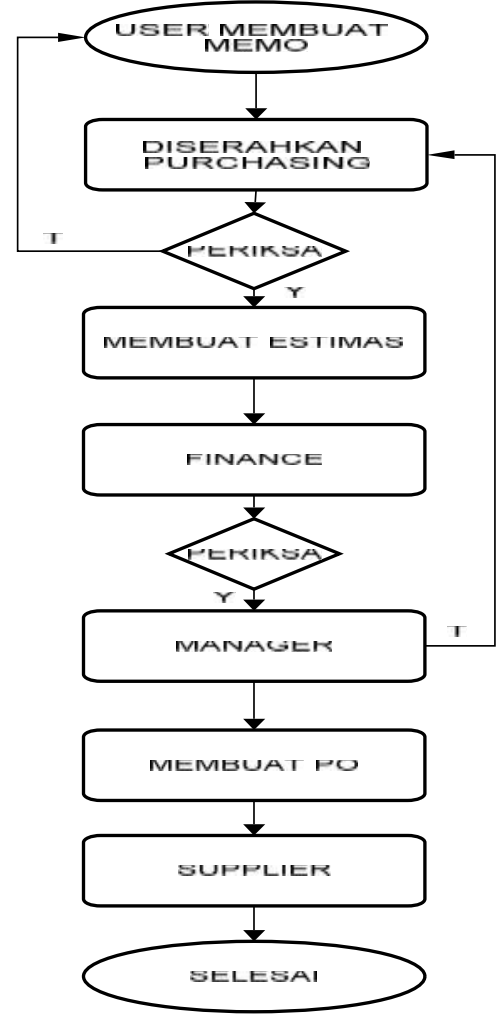

Gambar 2. Analisa Sistem Berjalan 


\section{Metode Simple Additive Weight}

Salah satu metode penyelesaian masalah yang bisa diterapkan dalam sistem pendukung keputusan adalah dengan menggunakan metode simple additive weight $(S A W)$. Metode $S A W$ sering juga dikenal istilah metode penjumlahan terbobot. Konsep dasar metode $S A W$ adalah mencari penjumlahan terbobot dari rating kinerja pada setiap alternatif dari semua atribut. Metode $S A W$ membutuhkan proses normalisasi matriks keputusan (X) ke suatu skala yang dapat diperbandingkan dengan semua rating alternatif yang ada. [5]

Langkah penyelesaian simple sdditive weight (SAW) adalah sebagai berikut:

1) Menentukan kriteria-kriteria yang akan dijadikan acuan dalam pengambilan keputusan, yaitu $\mathrm{Ci}$.

2) Menentukan rating kecocokan setiap alternatif pada setiap kriteria.

3) Membuat matriks keputusan berdasarkan kriteria (Ci), kemudian melakukan normalisasi matriks berdasarkan persamaan yang disesuaikan dengan jenis atribut (atribut keuntungan ataupun atribut biaya) sehingga diperoleh matriks ternormalisasi R.

4) Hasil akhir diperoleh dari proses perankingan yaitu penjumlahan dari perkalian matriks ternormalisasi $\mathrm{R}$ dengan vektor bobot sehingga diperoleh nilai terbesar yang dipilih sebagai alternatif terbaik (Ai) sebagai solusi.

Formula untuk melakukan normalisasi pada matriks $\mathrm{X}$ adalah sebagai berikut:

$$
\begin{gathered}
R_{i j}=\frac{x_{i j}}{\max _{i}\left(x_{i j}\right)} \text { Jika j adalah keuntungan (benefit) } \\
R_{i j}=\frac{\min _{i}\left(x_{i j}\right)}{x_{i j}} \text { Jika j adalah biaya (cost) }
\end{gathered}
$$

Keterangan:

$\mathrm{R}_{\mathrm{ij}} \quad=$ Nilai rating kinerja ternormalisasi

$\mathrm{X}_{\mathrm{ij}} \quad=$ Nilai atribut yang dimiliki setiap kriteria

$\operatorname{Max}_{\mathrm{ij}}=$ Nilai terbesar dari setiap kriteria

$\operatorname{Min}_{\mathrm{ij}}=$ Nilai terkecil dari setiap kriteria

Formula untuk melakukan perangkingan pada matriks $\mathrm{X}$ adalah sebagai berikut:

$$
V_{i}=\sum_{j=1}^{n} W_{j} R_{i j}
$$

Keterangan:

$\mathrm{V}_{\mathrm{ij}} \quad=$ Nilai akhir dari alternatif

$\mathrm{W}_{\mathrm{j}} \quad$ = Nilai bobot yang sudah ditentukan

$\mathrm{R}_{\mathrm{ij}} \quad=$ Nilai hasil normalisasi

\section{HASIL DAN PEMBAHASAN}

\author{
A. Perhitungan Menggunakan Metode Simple Additive \\ Weight (SAW)
}

Adapun langkah-langkah penyelesaian masalah dengan menggunakan metode simple additive weight (SAW) dijelaskan sebagai berikut:

1) Alternatif

Dalam metode $S A W$ terdapat Alternatif yang dibutuhkan untuk menentukan siapa yang akan terseleksi sebagai supplier terbaik. Adapun alternatifnya adalah sebagai berikut:

Tabel 1

Alternatif Supplier

\begin{tabular}{cl}
\hline Alternatif & \multicolumn{1}{c}{ Keterangan } \\
\hline A1 & PT. ALBAROKAH AL IMAM \\
A2 & PT. KOTENDER TEKNOLOGI \\
A3 & PT. MITRA MAS PERKASA \\
A4 & PT. HASILINDO JAYA INDONESIA \\
A5 & PT. ORISOL INDONESIA MACHINERY \\
A6 & PT. PETROTEC AIR BLOWER \\
A7 & PT. JEA YEU INDONESIA \\
A8 & CV. GL JAYA TEKNIK \\
A9 & CV. BORNEO PUTRA \\
A10 & PT. BERKAT AMINDO
\end{tabular}

2) Kriteria/Atribut

Dalam metode $S A W$ terdapat kriteria yang dibutuhkan untuk menentukan siapa yang akan terseleksi sebagai supplier terbaik. Adapun kriterianya adalah sebagai berikut:

Tabel 2

Kriteria/Atribut

\begin{tabular}{cl}
\hline Kriteria & \multicolumn{1}{c}{ Keterangan } \\
\hline $\mathrm{C} 1$ & Harga Barang \\
$\mathrm{C} 2$ & Kualitas Barang \\
$\mathrm{C} 3$ & Receive \\
$\mathrm{C} 4$ & Waktu Pengiriman \\
\hline
\end{tabular}

\section{3) Pembobotan Keputusan}

Pembobotan ini dilakukan untuk memberi bobot yang tepat untuk setiap supplier. Untuk lebih jelasnya akan dijelaskan dalam tabel dibawah ini:

Tabel 3

Pembobotan Kriteria

\begin{tabular}{clcl}
\hline Kriteria & \multicolumn{1}{c}{ Kriteria } & Bobot & Keterangan \\
\hline C1 & Harga Barang & 30 & Baik \\
C2 & Kualitas Barang & 40 & Sangat Baik \\
C3 & Receive & 20 & Cukup \\
C4 & Waktu Pengiriman & 10 & Kurang \\
\hline
\end{tabular}

Tabel 4

Pembobotan Sub Kriteria

\begin{tabular}{clcc}
\hline Kriteria & Kriteria & Sub Kriteria & Nilai \\
\cline { 1 - 3 } C1 & Harga Barang & Dibawah Harga PO & 15 \\
& & Harga Sama Dengan PO & 10 \\
& & Harga Diatas PO & 5 \\
C2 & Kualitas Barang & Rusak Dalam $<1-3$ bln & 10 \\
& & Awet $>3$ bln & 30 \\
C3 & Receive & Sesuai PO & 15 \\
& & Tidak Sesuai PO & 5
\end{tabular}


$\mathrm{C} 4$ Waktu Pengiriman $<10$ Har $>10$ Hari 8
2

4) Perhitungan Data Menggunakan Metode SAW

Berikut dijelaskan perhitungan data berdasarkan pengambilan contoh kasus pada penelitian ini.

Supplier pengiriman sparepart pada PT. Nikomas Gemilang, user mengajukan pembelian kepada departemen purchasing, setelah menerima data pembelian maka pihak purchasing akan memilih supplier yang tepat untuk pembelian sparepart yang dibutuhkan user. Adapun contoh kasus pembelian gear box pada beberapa supplier dan dari perusahaan menentukan harga net PO yaitu Rp 4.577.000.

Rekapitulasi data ditampilkan pada tabel dibawah ini:

Tabel 5

Rekapitulasi Data

\begin{tabular}{ccccc}
\hline $\begin{array}{c}\text { Alter- } \\
\text { natif }\end{array}$ & $\begin{array}{c}\text { Harga } \\
(\mathbf{C I})\end{array}$ & $\begin{array}{c}\text { Kualitas } \\
(\mathbf{C 2})\end{array}$ & $\begin{array}{c}\text { Receive } \\
(\mathbf{C 3})\end{array}$ & $\begin{array}{c}\text { Pengiriman } \\
\text { (C4) }\end{array}$ \\
\hline A1 & 4.589 .000 & Rusak 2.5 bulan & Sesuai & 14 hari \\
A2 & 5.000 .500 & Rusak 1.5 bulan & Tidak & 17 hari \\
A3 & 4.570 .000 & Rusak 1 bulan & Tidak & 6 hari \\
A4 & 4.600 .500 & Rusak 3 bulan & Sesuai & 9 hari \\
A5 & 4.850 .000 & Rusak 2 bulan & Sesuai & 10 hari \\
A6 & 5.000 .300 & Rusak 3 bulan & Tidak & 5 hari \\
A7 & 4.565 .000 & Rusak 2 bulan & Sesuai & 7 hari \\
A8 & 4.700 .900 & Rusak 4 bulan & Sesuai & 11 hari \\
A9 & 4.980 .000 & Rusak 2 bulan & Tidak & 15 hari \\
A10 & 4.577 .000 & Rusak 1 bulan & Sesuai & 4 hari \\
\hline
\end{tabular}

Dari alternatif dan kriteria yang telah ditentukan maka tabel rating kecocokan setiap alternatif .

Tabel 6

Kecocokan Alternatif Pada Setiap Kriteria

\begin{tabular}{ccccc}
\hline Alternatif & $\begin{array}{c}\text { Harga } \\
\text { (CI) }\end{array}$ & $\begin{array}{c}\text { Kualitas } \\
\text { (C2) }\end{array}$ & $\begin{array}{c}\text { Receive } \\
\text { (C3) }\end{array}$ & $\begin{array}{c}\text { Pengiriman } \\
\text { (C4) }\end{array}$ \\
\hline A1 & 5 & 10 & 15 & 2 \\
A2 & 5 & 10 & 5 & 2 \\
A3 & 15 & 10 & 5 & 8 \\
A4 & 5 & 10 & 15 & 8 \\
A5 & 5 & 10 & 15 & 8 \\
A6 & 5 & 10 & 5 & 8 \\
A7 & 15 & 10 & 15 & 8 \\
A8 & 5 & 30 & 15 & 2 \\
A9 & 5 & 10 & 5 & 2 \\
A10 & 10 & 10 & 15 & 8 \\
\hline Min & 5 & 10 & 5 & 2 \\
Max & 15 & 30 & 15 & 8 \\
\hline
\end{tabular}

Dari Tabel VI diubah kedalam matriks keputusan X dengan data:

$$
X=\left[\begin{array}{cccc}
5 & 10 & 15 & 2 \\
5 & 10 & 5 & 2 \\
15 & 10 & 5 & 8 \\
5 & 10 & 15 & 8 \\
5 & 10 & 15 & 8 \\
5 & 10 & 5 & 8 \\
15 & 10 & 15 & 8 \\
5 & 30 & 15 & 2 \\
5 & 10 & 5 & 2 \\
10 & 10 & 15 & 8
\end{array}\right]
$$

Selanjutnya dilakukan proses normalisasi pada matriks $\mathrm{X}$ dengan hasil sebagai berikut:

a) Untuk Kriteria Harga:

$$
\begin{aligned}
& R 11=\frac{5}{M A X(5,5,15,5,5,5,15,5,5,10)}=\frac{5}{15}=0,33 \\
& R 12=\frac{5}{M A X(5,5,15,5,5,5,15,5,5,10)}=\frac{5}{15}=0,33 \\
& R 13=\frac{15}{M A X(5,5,15,5,5,5,15,5,5,10)}=\frac{5}{15}=1,00 \\
& R 14=\frac{5}{M A X(5,5,15,5,5,5,15,5,5,10)}=\frac{5}{15}=0,33 \\
& R 15=\frac{5}{M A X(5,5,15,5,5,5,15,5,5,10)}=\frac{5}{15}=0,33 \\
& R 16=\frac{5}{M A X(5,5,15,5,5,5,15,5,5,10)}=\frac{5}{15}=0,33 \\
& R 17=\frac{15}{M A X(5,5,15,5,5,5,15,5,5,10)}=\frac{5}{15}=1,00 \\
& R 18=\frac{5}{M A X(5,5,15,5,5,5,15,5,5,10)}=\frac{5}{15}=0,33 \\
& R 19=\frac{5}{M A X(5,5,15,5,5,5,15,5,5,10)}=\frac{5}{15}=0,33 \\
& R 110=\frac{5}{M A X(5,5,15,5,5,5,15,5,5,10)}=\frac{5}{15}=0,66
\end{aligned}
$$

b) Untuk Kriteria Kualitas:

$$
\begin{aligned}
& R 21=\frac{10}{\operatorname{MAX}(10,10,10,10,10,10,10,30,10,10)}=\frac{10}{30}=0,33(15) \\
& R 22=\frac{10}{\operatorname{MAX}(10,10,10,10,10,10,10,30,10,10)}=\frac{10}{30}=0,33(16) \\
& R 23=\frac{10}{\operatorname{MAX}(10,10,10,10,10,10,10,30,10,10)}=\frac{10}{30}=0,33(17) \\
& R 24=\frac{10}{\operatorname{MAX}(10,10,10,10,10,10,10,30,10,10)}=\frac{10}{30}=0,33(18)
\end{aligned}
$$




$$
\begin{aligned}
& R 25=\frac{10}{\operatorname{MAX}(10,10,10,10,10,10,10,30,10,10)}=\frac{10}{30}=0,33(19) \\
& R 26=\frac{10}{M A X(10,10,10,10,10,10,10,30,10,10)}=\frac{10}{30}=0,33(20) \\
& R 27=\frac{10}{\operatorname{MAX}(10,10,10,10,10,10,10,30,10,10)}=\frac{10}{30}=0,33(21) \\
& R 28=\frac{30}{\operatorname{MAX}(10,10,10,10,10,10,10,30,10,10)}=\frac{30}{30}=1,00 \\
& R 29=\frac{10}{\operatorname{MAX}(10,10,10,10,10,10,10,30,10,10)}=\frac{10}{30}=0,33(23) \\
& R 210=\frac{10}{\operatorname{MAX}(10,10,10,10,10,10,10,30,10,10)}=\frac{10}{30}=0,33(24) \\
& \text { c) Untuk Kriteria Receive: } \\
& R 31=\frac{15}{\operatorname{MAX}(15,5,5,15,15,5,15,15,5,15)}=\frac{15}{15}=1,00 \\
& R 32=\frac{5}{\operatorname{MAX}(15,5,5,15,15,5,15,15,5,15)}=\frac{5}{15}=0,33 \\
& R 33=\frac{5}{\operatorname{MAX}(15,5,5,15,15,5,15,15,5,15)}=\frac{5}{15}=0,33 \\
& R 34=\frac{15}{\operatorname{MAX}(15,5,5,15,15,5,15,15,5,15)}=\frac{15}{15}=1,00 \\
& R 35=\frac{15}{M A X(15,5,5,15,15,5,15,15,5,15)}=\frac{15}{15}=1,00 \\
& R 36=\frac{5}{\operatorname{MAX}(15,5,5,15,15,5,15,15,5,15)}=\frac{5}{15}=0,33 \\
& R 37=\frac{15}{\operatorname{MAX}(15,5,5,15,15,5,15,15,5,15)}=\frac{15}{15}=1,00 \\
& R 38=\frac{15}{M A X(15,5,5,15,15,5,15,15,5,15)}=\frac{15}{15}=1,00 \\
& R 39=\frac{5}{\operatorname{MAX}(15,5,5,15,15,5,15,15,5,15)}=\frac{5}{15}=0,33 \\
& R 310=\frac{15}{\operatorname{MAX}(15,5,5,15,15,5,15,15,5,15)}=\frac{15}{15}=1,00 \\
& \text { d) Untuk Kriteria Pengiriman: } \\
& R 41=\frac{2}{\operatorname{MAX}(2,2,8,8,8,8,8,2,2,8)}=\frac{2}{8}=0,25 \\
& R 42=\frac{2}{\operatorname{MAX}(2,2,8,8,8,8,8,2,2,8)}=\frac{2}{8}=0,25 \\
& R 43=\frac{8}{\operatorname{MAX}(2,2,8,8,8,8,8,2,2,8)}=\frac{8}{8}=1,00 \\
& R 44=\frac{8}{\operatorname{MAX}(2,2,8,8,8,8,8,2,2,8)}=\frac{8}{8}=1,00
\end{aligned}
$$

$$
\begin{aligned}
& R 45=\frac{8}{\operatorname{MAX}(2,2,8,8,8,8,8,2,2,8)}=\frac{8}{8}=1,00 \\
& R 46=\frac{8}{\operatorname{MAX}(2,2,8,8,8,8,8,2,2,8)}=\frac{8}{8}=1,00 \\
& R 47=\frac{8}{\operatorname{MAX}(2,2,8,8,8,8,8,2,2,2,8)}=\frac{8}{8}=1,00 \\
& R 48=\frac{2}{\operatorname{MAX}(2,2,8,8,8,8,8,2,2,8)}=\frac{2}{8}=0,25 \\
& R 49=\frac{2}{\operatorname{MAX}(2,2,8,8,8,8,8,2,2,2,8)}=\frac{2}{8}=0,25 \\
& R 410=\frac{8}{\operatorname{MAX}(2,2,8,8,8,8,8,2,2,8)}=\frac{8}{8}=1,00
\end{aligned}
$$

Selanjutnya dilakukan proses perangkingan pada matriks $X$ dengan hasil sebagai berikut:

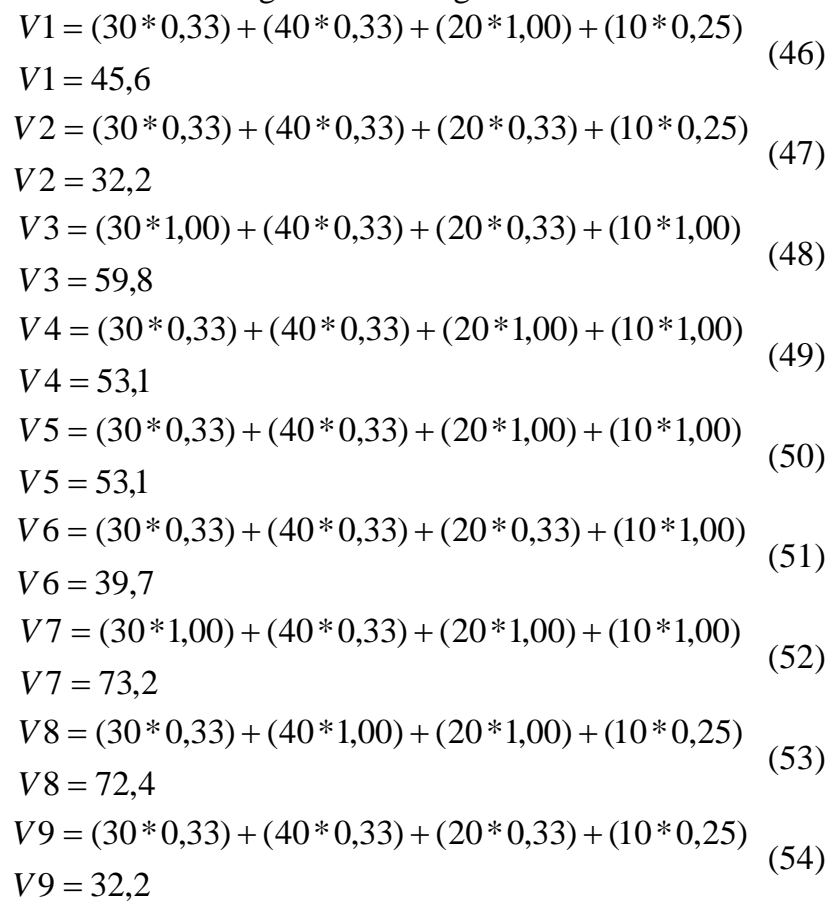




$$
\begin{aligned}
& V 10=(30 * 0,66)+(40 * 0,33)+(20 * 1,00)+(10 * 1,00) \\
& V 10=63
\end{aligned}
$$

Hasil perangkingan didapat nilai terbesar ada pada V7 yaitu sebesar 73,2. Hal menunjukkan bahwa V7 merupakan alternatif terbaik dalam pemilihan supplier pada PT. Nikomas Gemilang berdasarkan contoh data kasus yang ada.

\section{B. Perancangan Sistem}

Perancangan sistem dalam penelitian ini menggunakan diagram use case. Berikut rancangan diagram use case sistem:

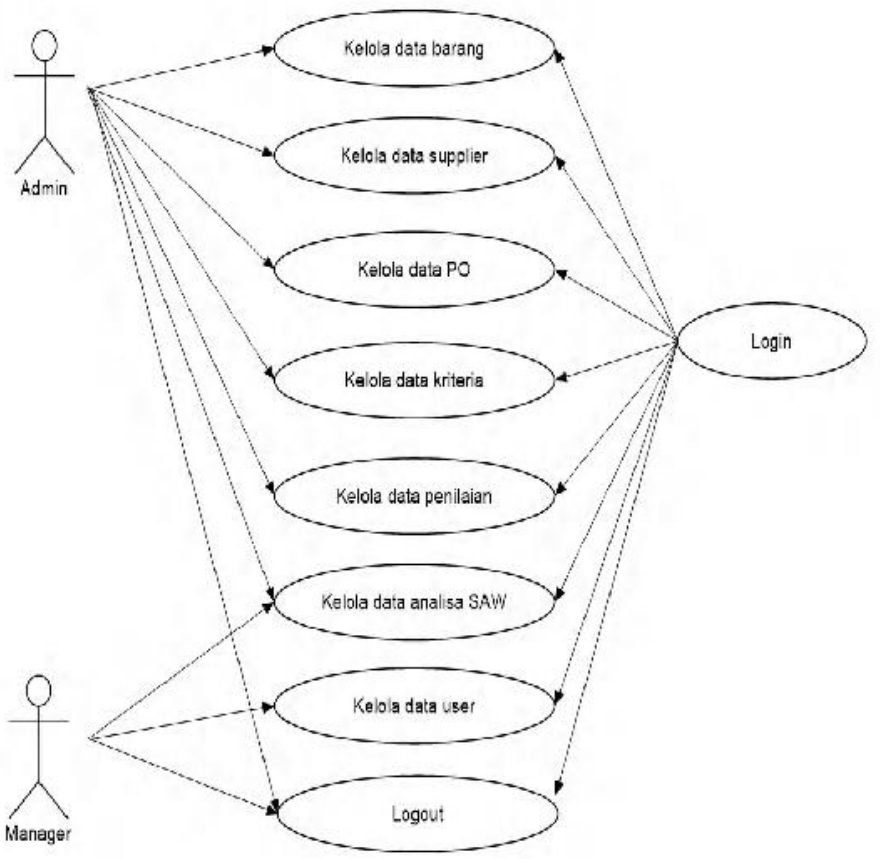

Gambar 3. Diagram Use Case Sistem

\section{Implementasi User Interface}

Berikut implementasi dari tampilan user interface dari sistem pendukung keputusan:

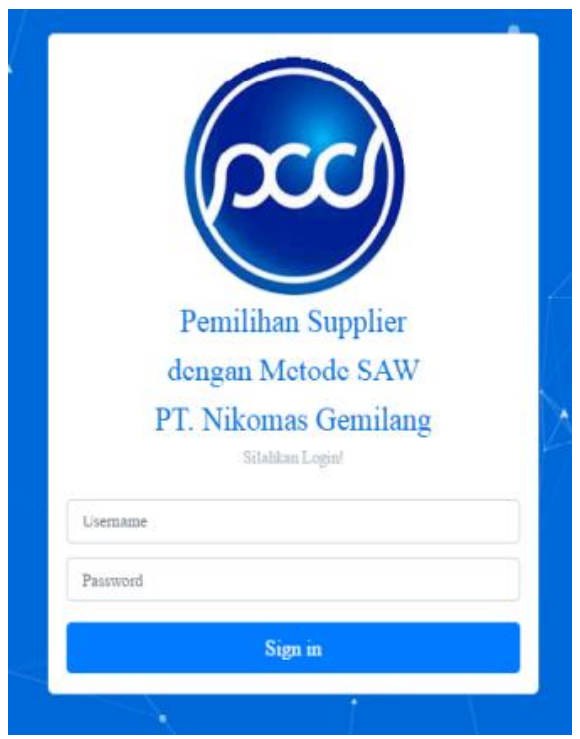

Gambar 4. Tampilan Halaman Login

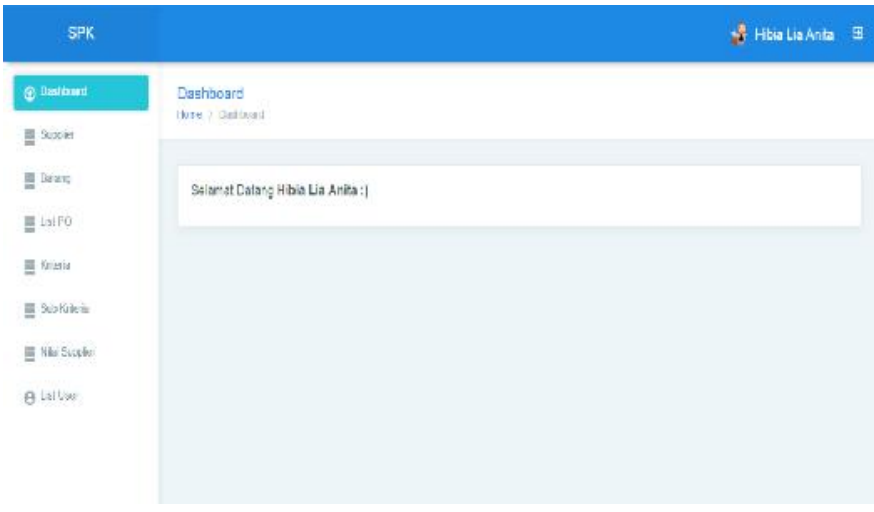

Gambar 5. Tampilan Halaman Utama Admin

\section{KESIMPULAN}

Sistem pendukung keputusan pemilihan supplier ini dirancang dan diimplementasikan pada PT. Nikomas Gemilang untuk membantu memilih supplier berdasarkan beberapa kriteria yang telah ditentukan.

Terdapat empat kriteria yang menjadi aspek penentuan dalam pemilihan supplier pada PT. Nikomas Gemilang. Empat kriteria tersebut adalah harga barang, kualitas barang, receive dan waktu pengiriman.

Berdasarkan perhitungan dengan menggunakan metode simple additive weight, sistem pendukung keputusan ini mampu melakukan perhitungan yang sesuai dengan kriteria serta pembobotan untuk menghasilkan output yang dapat digunakan sebagai bahan pendukung keputusan dalam memilih beberapa alternatif supplier yang ada.

\section{REFERENSI}

[1] Setiawan, Agung, (2010) "Sistem Pendukung Keputusan Pemilihan Supplier Material Dengan Metode Analytical Hierarchy Process (Studi Kasus : PT. Ajinomoto Indonesia Mojokerto Factory)", Thesis, Sistem Informasi, ITS, Surabaya.

[2] EL Ruskan, A Ibrahim, DC Hartini (2013)."Sistem Pendukung Keputusan Pemilihan Hotel Di Kota Palembang Dengan Metode Simple Additive Weighting(SAW)" Jurnal Sistem Informasi (JSI), Vol. 5, No. 1, April 2013.

[3] Setiaji, Pratomo, (2012) "Sistem Pendukung Keputusan Dengan Metode Simple Additive Weighting," Jurnal 
Simetris Vol.1 No.1 Universitas Muria Kudus, Kudus, 2012, ISSN 2252-4983 e-ISSN 2549-3108.

[4] GW, Sasmito (2017). "Penerapan Metode Waterfall Pada Desain Sistem Informasi Geografis Industri Kabupaten Tegal “Jurnal Pengembangan IT (JPIT), Vol.2, No 1, 1 Januari 2017, ISSN: 2477-5126 e-ISSN: 2548-9356.

[5] Eniyati, S. (2011). Perancangan Sistem Pendukung Pengambilan Keputusan untuk Penerimaan Beasiswa dengan Metode SAW (Simple Additive Weighting). Dinamik, $16 \quad$ (2). $\quad$ Retrieved from https://www.unisbank.ac.id/ojs/index.php/fti1/article/vie $\mathrm{w} / 364$ 